\author{
TOMASZ OBIALA* \\ Uniwersytet Szczeciński
}

\title{
THE SOCIOPHONOLOGY OF /L/ AND /R/ VOCALISATION AND INTRUSION
}

The phonemes $/ \mathrm{r} /$ and $/ 1 /$ are both [+consonantal], [+continuant], [+voice], [+coronal] and [+sonorant]. Both of them undergo the process known as vocalisation and also occur as intrusive consonants in certain environments. Therefore, it might be valid to say that $/ \mathrm{r} /$ and $/ 1 /$ show a certain extent of similarity. However, when one looks into the sociophonology of these two phonemes, one finds that there are as many similarities as differences between them.

Vocalisation and intrusion of $/ 1 /$ and $/ \mathrm{r} /$ have been investigated by a number of researchers. The intrusion of $/ \mathrm{r} /$ has been studied considerably more widely, among others, by Wells (1982), Trudgill (1986), Gick (1999), Uffmann (2007). Intrusive /1/ has been studied far less, probably due to its considerably smaller occurrence. Linguists who investigated this phonological phenomenon are, among others, Gick (1999) and (2002), Wells (1982) and McMahon (2000). As for the vocalisation of the two phonemes, /1/ was investigated by Johnson and Britain (2003), Wells (1982) and Trudgill (1986), whereas /r/ was researched by McMahon (2000), Wells (1982), Gick (1999, 2002).

According to Uffmann (2007: 452), the intrusion of $/ r$ / can occur only if three conditions are fulfilled. The first one is that $/ \mathrm{r} / \mathrm{can}$ only be introduced in a hiatus position, which means that one can expect this phoneme to be inserted in between two syllables. Gick (1999: 30) refers to this as "presence of a non-historical consonant between two heterosyllabic vowels". The second condition outlined by Uffmann (2007: 452) is that it can only take place within a non-rhotic accent e.g.

* Tomasz Obiała - magister, wykładowca w Katedrze Filologii Angielskiej Uniwersytetu Szczecińskiego; e-mail: tomasz.obiala@usz.edu.pl. 
Received Pronunciation in the UK or the area of eastern Massachusetts in the USA, which is confirmed by Gick (ibid.). Finally, it will follow only non-high vowels such as [a, o:, a:]. Wells (1982: 284) implies that 'intrusive' $/ \mathrm{r}$ / is the one that is "unhistorical, not corresponding to the spelling" and so claims McMahon (2000: 232) by saying that this phenomenon is unetymological. She also adds, which confirms the standpoints of Uffmann (2007) and Gick (1999), that intrusive / $\mathrm{r}$ / "appears intervocalically (...) word-internally and across word-boundaries". It is perhaps worth taking a look at her examples:

saw [s: $]+$ ing $[\mathrm{I} \eta]] \rightarrow[\mathrm{s}: \mathbf{r} \mathrm{I} I \mathrm{y}]$ - intrusive $/ \mathrm{r} /$ inserted within one word law and order [lo:rəno:də], idea is [ardırız] intrusive $/ \mathrm{r} /$ inserted across word-boundaries

Intrusive /1/ is considerably less spread across the Anglophone world. Wells's account (1982: 344-345) of this phenomenon maintains that its origin pertains to hypercorrection after the loss of final /1/. Intrusive /1/ is restricted only to Bristol where $/ 1 /$ is added to words that have a word-final $/ \mathrm{\partial}$ / $/$ or the diphthong /əv/. Wells (1982: 344) writes that "Intrusive /1/ seems always to have been a pretty local phenomenon, not occurring beyond the boundaries of Avon; even within them it is by now quite rare". However, this is very much contradicted by a number of researchers who have found other places in the English-speaking world where this phoneme is inserted even though one does not expect it there. Gick (2002: 167) writes that intrusive /1/ is present in the south of the American state of Pennsylvania, but there are also some single references to this phenomenon in central Oklahoma, North Carolina (African American English), Northern Texas etc. (Gick 2002: 176). Gick continues by saying that intrusive /1/ seems to be enclosed within two regions: Mid-Atlantic states and northern Texas as well as Oklahoma. Gick (1999: 35) also adds that the intrusive /1/ has been associated with the working class and rural dialects in the above-mentioned regions. Finally, it must be observed that the insertion of the phoneme /1/ brings about a situation where two distinct words behave like two homophones and as a result of that, we obtain homophonic pairs such as idea/ideal, area/aerial or mango/mangle. Gick (2002: 178) also provides a number of examples where /1/ occurs word-internally. These include words such as draw[1]ing for drawing. The same researcher also mentions (Gick 2002: 172) that "some speakers also extend l-intrusion to words ending in /a/ (e.g. my bra[1] is coming undone)". 
It is important to start with the geographical spread of these phenomena. At the first sight, it may be said that the distribution of the intrusion of $/ 1 /$ and $/ \mathrm{r} /$ occurs in entirely distinct areas. The intrusive /r/ occurs only in the non-rhotic accents. Therefore, it will be present in certain parts of the following: England, Wales, the Eastern and Southern states of the USA, Australia, New Zealand and South Africa (McMahon 2000:234). The intrusive /1/, on the other hand, is very much popular in the USA, with a considerable presence in Pennsylvania. Intrusive $/ 1 /$ is therefore less spread around the world and seems to be a minor phenomenon in comparison to the intrusive $/ \mathrm{r} /$.

As far as the history of the two intrusive sounds is concerned, Trudgill (1986: 72) writes that "intrusive /r/ [is called] 'intrusive' because it is not 'historically justified' or present in the orthography". To understand it better, one should look at how McMahon (2000) explains that some accents of English became non-rhotic. At the stage when English was rhotic, pre-/r/ Breaking happened and, consequently, the word [bi:r] became [bi:ər] (beer) or [fair] changed into [faiər] (fire). The next step was Pre-Schwa Laxing/Shortening where, for example, [bi:ər] became [bıər] and [faiər] changed into [faır]. The final stage is known as $/ \mathrm{r} /$-Deletion, as a result of which $/ \mathrm{r} /$ was dropped and the pronunciation [farrr] took the form of [fare]. However, this process continued and some of the words ending in $/ \mathrm{p}$ / and $/ \mathrm{v} / \mathrm{yielded}$ a long $/ \mathrm{o} /$. This provides a very good base for finding out why one may find a linking $/ \mathrm{r} /$ in non-rhotic English. (Linking/r/ differs from intrusive $/ \mathrm{r} /$ in that it is historically-motivated and present in the orthography). The phoneme $/ \mathrm{r}$ / was deleted in a word-final, postvocalic position as shown above, however once the word is followed by another word beginning in a vowel, the phoneme /r/ is reinserted as in the following example - far [fa:] but far away [fa:rəwer], more [mo:] and more and [mo:rənd]. The case will pertain to the following vowels: /a/, /o:/, /a:/ and /3:/. However, as far as intrusive /r/ is concerned, it will only occur after vowels (Trudgill 1986: 72): /ı/ idea, /a:/ bra, /o:/ law and /a/ America. As opposed to the linking / $\mathrm{r} /$, the intrusive / $\mathrm{r} /$ will not appear after /3:/ because it derives from historical $\mathrm{V}+/ \mathrm{r} /$. To contrast this information about intrusive / $\mathrm{r}$ / with what we know about intrusive /1/ the following has to be said. Intrusive $/ 1 /$, like intrusive $/ \mathrm{r} /$ occurs only after some vowels, and predominantly after /o:/ (Gick 2002: 168). However, it is very easy to see that the ground for inserting $/ \mathrm{r} /$ is much more understandable than that of $/ 1 /$. This is because intrusive / $\mathrm{r} /$ may be inserted due to overgeneralizations which standardize introducing /r/ after certain vowels, no matter what the spelling is. The speakers seem to form 
an analogy and so both for and law ending in /s:/ will end up with an intrusive /r/ when a vowel-initial word follows. This is summarized by Wells (1982: 223) who says that "intrusive / $\mathrm{r}$ / arises essentially from the natural tendency to give identical treatment to words with identical endings". Intrusive /1/ has no such grounding since it is neither present in the orthography nor is it historically justified. However, this may be further developed when more attention is paid to the processes of vocalisation, which is going to be explained below, putting a special emphasis on the similarity of this process with regard to both /r/ and /1/ in the light of a synchronic analysis.

Wells (1982: 313) writes that "vocalisation [of $/ 1 /]$ is a sound change still very much in progress; speakers are by no means consistent. Vocalisation, or to be more precise $r$ dropping" is according to him finished, as he writes that (Wells 1992: 218). "RP has eliminated historical / $r$ / except in the environment of a following vowel". This came about in the eighteenth century, when $/ \mathrm{r} /$ disappeared before a consonant or in absolute final position. It should be said that R Dropping will not pertain to $/ \mathrm{r} /$ in the word-initial position and that this phenomenon as a whole will only relate to the so-called non-rhotic accents (they have been listed here earlier) i.e. accents where $/ \mathrm{r} /$ is not pronounced in the post-vocalic position.

It has already been mentioned here that what made some Englishes nonrhotic is a set of three sound changes that happened over a period of approximately 150 years (McMahon 2000: 234). These changes were Pre-/r/ Breaking, Pre-Schwa Laxing/Shortening and finally / $\mathrm{r} /$-Deletion. In a nutshell, Pre-/r/ Breaking consisted in adding a schwa sound before $/ \mathrm{r} /$ but after consonants such as: / i: e: o: u: ai au/. Some examples have already been provided here, but to complement this list, there are some more, e.g. [mo:r] being changed into [mo:ər] or [taur] into [tau:ər]. Pre-Schwa Laxing/Shortening is a name for a process whereby the long vowels /i: e: o: u:/ were shortened and consequently what was yielded was a set of short vowels $\left[\begin{array}{lll}I & \boldsymbol{D} & v\end{array}\right]$. However, the most interesting process here is the $/ \mathrm{r} /$-Deletion that happened afterwards. As a result of that all post-vocalic $/ \mathrm{r} / \mathrm{s}$ were lost. This was not an abrupt process and McMahon (2000) has it that it must have been a gradual change. Jespersen (1909: 318 cited in McMahon 2000: 238) claims that $\mathrm{OE}$ and Middle English / $\mathrm{r}$ / was probably a trill in all positions and only then did it weaken to a tap, then an approximant, and consequently was lost in the non-rhotic accents /r/ was lost and what was left appeared to be vowels (both pure vowels and diphthongs). Although Longman Pronunciation Dictionary does not list citation forms such as [mo: $]$ ] for more, it still provides a number 


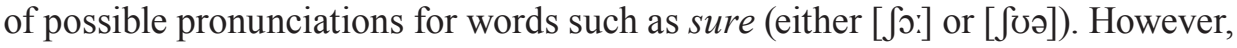
a very tangible proof of how $/ \mathrm{r} /$ has undergone vocalisation in non-rhotic accents is when one compares RP and American pronunciations as found in the said dictionary. The word chair said [tfeə] in RP and [t $\mathrm{fe}$ ? $\mathrm{r}]$ in General American English, beer [biə] and [bi? $\mathrm{r}$ ] respectively. The pronunciation just mentioned may be a little "contaminated" by / ?, nevertheless when one takes into account more complex lexemes, the British counterparts show a very visible vocalisation. The word chairman in RP is transcribed as ['teəmən] and in GenAm ['tfermən]. One can easily see that where American English has an /r/ phoneme, the RP accent in Britain has a corresponding vowel /a/ being, as one may presumably say, one of the vocalised forms of $/ \mathrm{r} /$. The other vowels that a vocalised $/ \mathrm{r} /$ follows (apart from /o/) are /a/ and /oo/ (Gick 1999: 31).

The vocalisation of /1/ starts with a more articulatory analysis of this phoneme. Without going into much history, it can be said that nowadays English has two allophones of/1/, namely, clear/1/ and dark/1/. Johnson and Britain (2007: 295) concisely differentiate these two allophones of /1/ by saying that the dark / $/ 11 /$ is a velarised form which involves "the retraction of the back of the tongue towards the velum", whereas the clear /1/ is what the name itself implies". Gimson and Cruttenden (1994: 182) mention a variation of the dark /1/ among various speakers, and they give a number of various vowels that make up a list of allophones of $/ \mathrm{Ht} /$. This is very much confirmed by Johnson and Britain (2007: 296) who maintain that "for the vocalisation to take hold, it is essential that dark /1/ has first developed". The first wave of vocalisation was in the $16^{\text {th }}$ century and, as a result of that a lateral consonant $/ 1 /$ is now absent in words such as calf, palm, talk and stalk i.e. after today's vowels /a:/ and /:2/ (Johnson and Britain 2007: 298). However, what is crucial for this discussion is the current trend of /1/ vocalisation in syllable codas which covers area of London, south-eastern England, West Yorkshire, the North, South Durham, Bristol or Philadelphia in the US, the inland south of the US etc. (Gick 2002, Johnson and Britain 2007). Johnson and Britain (2007) give a number of examples of this phenomenon: feel [fi:w], cool [ku:w], built [bi:wt], people [pi:pu] (/w/ replaces coda /1/ and /u/ replaces nuclear /1/). However, Wells (1982: 258) restricts this phenomenon to resulting in two vocoids: one usually rounded /o/ and a similar, but unrounded back/ $/ \mathrm{y} /$, although he mentions that the quality of these can vary. Wells (1982: 259) implies that R-Dropping brought about the emergence of a number of diphthongs (discussed earlier), and L-Vocalisation is similar to that is in much as that it is very likely 
to make some sounds receive a phonemic status of new diphthongs, such as /IU/

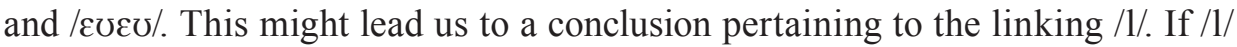
is lost, in the same way as it happened to / $\mathrm{r}$ / in the non-rhotic accents, then /1/ might have to follow the same route as $/ \mathrm{r} /$ in terms of reinsertion. It would not perhaps be a too far-fetched conclusion to say that if the word fill was pronounced as [fIw] or [fIo], then it would be very probable that such a word with /1/-vocalised word-final form would have its underlying /1/ reinserted whenever followed by another word which is vowel-initial. The result of that could be e.g. fill it [f 1 It]. Nevertheless, as it seems in terms of time, vocalisation of /1/ does not look to have undergone such a long process of creation as opposed to the vocalisation of $/ \mathrm{r} /$ which took a couple of hundreds of years and so we might have to wait some time before this process covers some greater areas of the Anglophone world.

Vocalisation of /1/ in the UK seems to look slightly different when compared to this phenomenon in the USA. Philadelphians are said to pronounce words like doll as [do:] and dollar as [do:ð] (Gick 2002: 171). Gick also emphasises two aspects of this process. The first is that it is interesting to see that $/ 1 /$ vocalisation may happen intervocalically as in dollar and then he mentions that it is very likely that there will be linking taking place when a word like [do:] is followed by a vowel-initial word (e.g. is) resulting in reinserting /1/ as follows [do: $1 \mathrm{Iz}]$.

$/ 1 /$ and $/ \mathrm{r} /$ vocalisation and intrusion have so far displayed a certain degree of similarity. However, when one looks at these phenomena from the angle of phonological domains, it is relatively easy to spot that $/ 1 /$ and $/ r /$ are, with the respect of vocalisation and intrusion, absolutely different as they occur is the opposite environments.

According to Roca and Johnson (1999: 480), intrusive /r/ will not occur in between two intonational phrases, even if one of them follows the other, when they are semantically unrelated. Consider the following two sentences:

\section{Don't sit on that sofa it's broken 2. Don't sit on that sofa, it's Mary}

In the examples above it is valid to say that r-insertion will determine their meaning. If intrusive $/ \mathrm{r} /$ is inserted in sofa rit's broken and sofa rit's Mary it will mean respectively that "the sofa is broken" and that "Mary is a sofa" and since there does not seem to be a semantic connection between the sofa and Mary, one does not insert / $\mathrm{r} /$ in that utterance so as not to link the utterance content. Roca and Johnson (1999) provide a similar grounding for the /1/ vocalisation pheno- 
menon. Given two sentences: 1. I feel ill. and 2. How do you feel, ill or fine?, it looks that $/ 1 /$ in feel in sentence number 2 will be vocalised as it is on the final edge of the first intonational phrase whereas feel in number 1 will not (generally) undergo vocalisation as it is within the same intonational phrase. It seems that intrusive $/ r$ / indicates a connection in terms of meaning between the two phrases whereas /1/ vocalisation indicates separation of two intonational phrases, though still keeps some semantic link.

There are a number of conclusions to be drawn as far as the similarities and differences of $/ 1 /$ and $/ \mathrm{r} /$ intrusion and vocalisation are concerned. First of all, $/ 1 /$ and $/ \mathrm{r} /$ intrusions cover completely different geographical territories. Although they seem to follow the same vowel / $\mathrm{s} /$, intrusive $/ \mathrm{r} /$ is by far more justified in terms of the history of English. Vocalisation of $/ 1 /$ and $/ \mathrm{r} /$, on the other hand, shows that these two processes seem to be geographically restricted as they occur only in some selected areas of the Anglophone world. Moreover, vocalisation of / $r$ / turns out to be completed in the non-rhotic accents of English, whereas vocalisation of $/ 1 /$ is still on its way. Finally, vocalisation of $/ 1 /$ and intrusion of $/ \mathrm{r} /$ can occur on the edges of two intonational phrases that are semantically linked. Nevertheless, intrusive / $r$ / indicated a direct semantic link whereas /1/ vocalisation seem to indicate a break between two intonational phrases.

\section{References}

Gick B., 1999, A gesture-based account of intrusive consonants in English. Phonology 16 (1) $29-54$.

Gick B., 2002, The American Intrusive-l in American Speech 77.2, pp. 167-183.

Gimson A., 1994 (1970), An Introduction to the Pronunciation of English [revised by A. Cruttenden], Edward Arnold, London.

Johnson W., Britain D., 2007, L-vocalisation as a natural phenomenon: Explorations in sociophonology, "Language Sciences" 29, pp. 294-315.

McMahon A., 2000, Lexical Phonology and the History of English, CUP, Cambridge.

Roca I., Johnson W., 1999, A Course in Phonology, Blackwell, Oxford.

Trudgill P., 1986, Dialects in Contact, New York: B. Blackwell, Oxford.

Uffmann C., 2007, Intrusive [r] and Optimal Epenthetic Consonants, "Language Sciences" 29 (2-3), pp. 334-359.

Wells J., 1982, Accents of English. 3 Volumes, CUP, Cambridge.

Wells J., 2003, Longman Pronunciation Dictionary, Longman, Harlow. 


\section{Summary}

The article presents on overview of the processes of vocalisation and intrusion on the basis of two contemporary English sonorant phonemes: /1/ and /r/. The study looks at the geographical spread of these phonological changes and discusses their historical motivation in order to present the main similarities and differences in the realizations of the two sounds. Finally, it presents the current status of the process of 1-vocalisation occurring in the British Isles, which is one of the most recent phenomena to be observed in the language change.

Keywords: sociophonology, vocalisation, intrusion, sonorants

\section{SOCJOFONOLOGIA WOKALIZACJI I INTRUZJI PHONEMÓW /L/ I /R/}

\section{Streszczenie}

Artykuł prezentuje przegląd procesów intruzji i wokalizacji w oparciu o dwa fonemy występujące we współczesnym języku angielskim: /1/ oraz/r/. Przeprowadzona analiza zwraca uwagę na geograficzne występowanie tych procesów i omawia ich historyczne uzasadnienie tak, aby zaprezentować podobieństwa i różnice w realizacji obu fonemów. Omówiony zostaje również współczesny proces wokalizacji fonemu /1/ na Wyspach Brytyjskich, będący jedną z najbardziej aktualnych zmian w języku angielskim.

Słowa kluczowe: socjofonologia, wokalizacja, intruzja, sonoranty 